\title{
Systematic Study of the Genus Vogesella gen. nov. and Its Type Species, Vogesella indigofera comb. nov.
}

\author{
D. JAY GRIMES, ${ }^{1 *}$ CARL R. WOESE, ${ }^{2}$ MICHAEL T. MACDONELL, ${ }^{3} \dagger$ AND RITA R. COLWELL ${ }^{3}$ \\ Environmental Sciences Division, ER-74, Office of Energy Research, U.S. Department of Energy, \\ Germantown, Maryland 20874-1290 ; Department of Microbiology, University of Illinois, \\ Urbana, Illinois $61801^{2}$; and University of Maryland Biotechnology Institute, \\ University of Maryland System, College Park, Maryland $20740^{3}$
}

\begin{abstract}
A blue-pigmented colony that had a metallic copper-colored sheen was isolated in 1973 from a standard spread plate count preparation of oxidation pond sediment. Over the next 11 years, an additional 12 strains of blue-pigmented bacteria were isolated from freshwater samples and compared to several reference strains of bacteria. Morphological and biochemical tests revealed that these 13 isolates were very similar to [Pseudomonas] indigofera ATCC $19706^{\mathrm{T}}(\mathrm{T}=$ type strain) and ATCC 14036. A numerical analysis (in which simple matching similarity coefficients were clustered by the unweighted pair group mathematical averaging method) of morphological and biochemical characteristics revealed $90.0 \%$ relatedness between the 13 isolates and $[P$.] indigofera ATCC 19706 $^{\mathrm{T}}$ and ATCC 14036 and $73.6 \%$ relatedness between the 13 isolates and a cluster containing Burkholderia cepacia ATCC $25416^{\mathrm{T}}$, Janthinobacterium lividum ATCC $12473^{\mathrm{T}}$, and the Pseudomonas species tested. A phylogenetic analysis, in which both 5S rRNA and 16S rRNA were used, also revealed that the 13 isolates were closely related to each other and to strains ATCC $19706^{\mathrm{T}}$ and ATCC 14036. In addition, both 5S rRNA and 16S rRNA analyses demonstrated that the isolates and strains ATCC $19706^{\mathrm{T}}$ and ATCC 14036 were members of the beta subdivision of the Proteobacteria and were closely related to Chromobacterium violaceum ATCC $12742^{\mathrm{T}}$ but sufficiently distinct to warrant placement in a new genus. Accordingly, we propose that the 13 isolates and strains ATCC $19706^{T}$ and ATCC 14306 be placed in the genus Vogesella gen. nov., which is named in honor of Otto Voges, who first isolated and described this blue-pigmented eubacterium in 1893. We also propose that $[P$.] indigofera be renamed Vogesella indigofera comb. nov. and designated the type species of the genus; strain ATCC 19706 is the type strain of this species.
\end{abstract}

An unusual blue-pigmented colony that had a metallic copper-colored sheen was isolated by one of us (D.J.G.) in 1973 from a standard spread plate count preparation of oxidation pond sediment. Fed by water from the La Crosse River in La Crosse, Wis., the pond from which the sediment was obtained was used for disposal of chemical wastes for nearly 20 years. The colony was purified, characterized, and, because of pigment similarities, compared to [Pseudomonas] indigofera ATCC $19706^{\mathrm{T}}$ ( $\mathrm{T}=$ type strain) by Kolar (19a), who concluded that the organism was sufficiently different from $[P$.] indigofera ATCC $19706^{\mathbf{T}}$ to justify naming it a new species, "Pseudomonas aenacaerulea." Kolar based this decision on the absence of sero-identity and on a $3.5 \mathrm{~mol} \%$ difference in the $\mathrm{G}+\mathrm{C}$ contents of the two species. However, in a later numerical taxonomic study of pigmented bacteria obtained from the Chesapeake Bay, Austin and Colwell (1) found that " $P$. aenacaerulea" and $[P$.] indigofera (both donated by D.J.G.) were closely related to each other $(S, \geq 70 \%)$ and to a phenon that was identified as Chromobacterium spp. (similarity [S], $\geq 60 \%$ ), but were significantly different phenotypically from other Pseudomonas spp. included in their data matrix.

Between 1973 and 1980, colonies morphologically similar to $[P$.] indigofera colonies were consistently observed in standard spread plate count preparations of both water and sediment samples collected from the Mississippi River. In 1984, we isolated similar colonies from water samples collected from the Potomac River $500 \mathrm{~m}$ upstream from Washington National

\footnotetext{
* Corresponding author. Present address: Institute of Marine Sciences, University of Southern Mississippi, P.O. Box 7000, Ocean Springs, MS 39566-7000. Phone: (601) 872-4211.
}

$\dagger$ Present address: Ransom Hill Bioscience, Inc., Ramona, CA 92065.
Airport. An appreciation for the frequency of occurrence of these bacteria in natural aquatic systems was obtained during 1975, when 310 water and sediment samples from the Mississippi River were analyzed by the standard spread plate count method. Approximately 130,000 colonies were examined, and $70(0.05 \%)$ exhibited the characteristic metallic blue pigmentation. In the Potomac River samples, a 10-fold-greater frequency, of isolation $(0.45 \%)$ was observed. However, the latter value was based on 900 colonies obtained from three different water samples collected at the same sampling time (i.e., the same season of the year and sampling location on the Potomac River).

Because the bacteria described above appeared to be a consistent feature of freshwater bacterial communities in terms of temporal and spatial distribution, we decided to conduct an investigation of metallic blue-pigmented pseudomonads. Perusal of the Approved Lists of Bacterial Names (40) revealed that the epithet of $[P$.$] indigofera had been retained, and$ Bergey's Manual of Systematic Bacteriology (20) and Bergey's Manual of Determinative Bacteriology (17) each contained a description of the species, based largely on the description of Elazari-Volcani (9) and on unpublished carbon source data provided by Palleroni (36). However, other than the data reported by McFadden and Howes in 1961 (32), no new information has been reported for $[P$.] indigofera.

In this paper, we describe morphological, biochemical, and molecular genetic attributes, as well as phylogenetic relationships, of 15 strains of metallic blue-pigmented pseudomonads determined in the first polyphasic taxonomic study (33) of $[P$.] indigofera and related strains. We concluded that $[P$.] indigofera should be placed in a new genus, Vogesella gen. nov., that Vogesella indigofera comb. nov. should be designated the type species, and that strain ATCC 19706 should be designated the 
TABLE 1. Reference cultures and isolates used in this study

\begin{tabular}{|c|c|c|c|}
\hline Strain & Source $^{a}$ & Origin & Year of isolation \\
\hline \multicolumn{4}{|l|}{ Study isolates } \\
\hline JG3 $(=$ ATCC 35906) & D.J.G. & Oxidation pond sediment ${ }^{b}$ & 1973 \\
\hline JG5 & D.J.G. & Pool 9 water ${ }^{c}$ & 1979 \\
\hline JG6 & D.J.G. & Pool 9 water ${ }^{c}$ & 1979 \\
\hline JG7 (= ATCC 35907) & D.J.G. & Pool 9 water ${ }^{c}$ & 1979 \\
\hline JG9 & D.J.G. & Pool 9 water ${ }^{c}$ & 1979 \\
\hline JG10 & D.J.G. & Pool 9 water ${ }^{c}$ & 1979 \\
\hline JG11 & D.J.G. & Pool 9 water $^{c}$ & 1979 \\
\hline JG12 & D.J.G. & Pool 8 water ${ }^{c}$ & 1979 \\
\hline JG13 & D.J.G. & Pool 8 water ${ }^{c}$ & 1979 \\
\hline JG14 & D.J.G. & Potomac River water & 1984 \\
\hline JG15 (= ATCC 35908) & D.J.G. & Potomac River water & 1984 \\
\hline JG16 & D.J.G. & Potomac River water & 1984 \\
\hline $\mathrm{JG} 17(=$ ATCC 35909$)$ & D.J.G. & Potomac River water & 1984 \\
\hline \multicolumn{4}{|l|}{ Reference strains } \\
\hline [Pseudomonas] indigofera ATCC $19706^{\mathrm{T}}$ & ATCC & Garden soil & 1961 \\
\hline$[P$.$] indigofera ATCC 14036$ & ATCC & Ditch mud & 1939 \\
\hline P. aenuginosa ATCC $10145^{\mathrm{T}}$ & ATCC & & \\
\hline P. fluorescens ATCC $13525^{\mathrm{T}}$ & ATCC & Prefilter tanks (England) & 1951 \\
\hline P. putida ATCC $12633^{\mathrm{T}}$ & ATCC & Soil & \\
\hline P. syringae ATCC $19310^{\top}$ & ATCC & Lilac (Syringa vulgaris) & 1902 \\
\hline Burkholderia cepacia ATCC $25416^{\mathrm{T}}$ & ATCC & Rotting onion & 1948 \\
\hline Chromobacterium violaceum ATCC $12472^{\mathrm{T}}$ & ATCC & Freshwater, Malaya & \\
\hline Janthinobacterium lividum ATCC $12473^{\mathrm{T}}$ & ATCC & Soil, Michigan & \\
\hline
\end{tabular}

\footnotetext{
"ATCC, American Type Culture Collection, Rockville, Md.; D.J.G., D. J. Grimes.

${ }^{b}$ Sediment from oxidation pond at Riverside Park, Federal Fish Control Laboratory, U.S. Fish and Wildlife Service, La Crosse, Wis.

${ }^{c}$ Water from navigation pool on the Upper Mississippi River.
}

type strain of this species. This new genus is named in honor of Otto Voges, who first isolated [Bacillus indigoferus] on gelatin plates inoculated with tap water from the central water supply system in Kiel, Germany, in 1893 (47). The remaining 14 strains which we studied are also placed in the genus Vogesella, but they cannot be classified as members of $V$. indigofera or any other species until DNA-DNA hybridization studies are performed.

\section{MATERIALS AND METHODS}

Source of strains. All isolates were picked from spread plates containing water and sediment samples on plate count agar (PCA) (Difco Laboratories, Detroit, Mich.) and incubated at 20 to $25^{\circ} \mathrm{C}$. Pure cultures were maintained in the following two ways: (i) in deeps of $0.5 \times$ plate count broth (Difco) stiffened with $0.3 \%$ agar (Difco) and stored at room temperature (ca. $20^{\circ} \mathrm{C}$ ); and (ii) frozen (under liquid nitrogen) in tryptic soy broth (Difco) containing 5\% glycerol. Cultures maintained in soft agar deeps have remained viable and culturable for more than 10 years. Reference strains were obtained from the American Type Culture Collection, Rockville, Md., and were maintained in a similar manner. The freshwater isolates and reference strains used in this study are listed in Table 1.

Morphological tests. All colonial and cellular morphological investigations were conducted by using standard procedures $(8,10,13,20,44)$. Flagellation was determined by the method of Mayfield and Inniss (31). The media used to stimulate pigmentation were blood agar, chocolate agar, chalk agar (45), tryptic soy agar (Difco) supplemented with hemoglobin (Difco), Mueller-Hinton agar (Difco), Thayer-Martin agar, milk agar, PCA (Difco) supplemented with $1 \%$ Tween 80 (Difco), spirit blue agar (Difco) supplemented with corn oil (Mazola), Pseudomonas agar F (Difco), and Pseudomonas agar $\mathrm{P}$ (Difco). The presence of poly- $\beta$-hydroxybutyrate (PHB) granules was determined by staining nitrogenlimited cells (grown on agar containing $2 \mathrm{~g}$ of $\mathrm{C}$ per liter and $0.02 \mathrm{~g}$ of $\mathrm{N}$ per liter) and PCA-grown cells with Sudan black B, followed by xylene clearing and safranin counterstaining (13).

Biochemical tests. Unless otherwise indicated, biochemical tests were done in accordance with methods described in standard reference manuals $(8,10,13,20$, $44)$, and media and peptones were obtained from Difco Laboratories. Indole production was detected in both $1 \%$ tryptone broth and SIM medium. Citrate utilization was investigated by using Simmons citrate agar, and Christensen urea agar was used to assay for urease. Production of $\mathrm{H}_{2} \mathrm{~S}$ was determined in both SIM medium and Kligler's iron agar. Nitrate reduction and denitrification were examined by using a medium described by Elliott et al. (10), and Durham vials were used to capture nitrogen gas; commercial nitrate broth (Difco) consistently gave negative reactions and was not used. Decarboxylation of amino acids (Sigma Chemical Co., St. Louis, Mo.) was investigated by using Moeller base, and all tubes were layered with sterile mineral oil. Oxidase was detected by the indophenol oxidase test $(10,36)$, as applied to early or crowded agar growth. Both early $(<18-\mathrm{h})$ and crowded agar growth exhibited little or no blue pigmentation that could have interfered with oxidase testing. Chitinase was detected with a medium described by West and Colwell (49), but the salt concentration was limited to $0.5 \%$; the assay medium used for pectinase contained (per liter of distilled $\left.\mathrm{H}_{2} \mathrm{O}\right) 5 \mathrm{~g}$ of tryptone, $2.5 \mathrm{~g}$ of yeast extract, $1 \mathrm{~g}$ of glucose, $1 \mathrm{~g}$ of $\mathrm{CaCl}_{2} \cdot \mathrm{H}_{2} \mathrm{O}, 5 \mathrm{~g}$ of $\mathrm{Na}_{2} \mathrm{HPO}_{4}, 25 \mathrm{mg}$ of bromothymol blue, $50 \mathrm{~g}$ of pectin, and enough $4 \mathrm{~N} \mathrm{KOH}$ to give a final $\mathrm{pH}$ of 7.5 . Esculin hydrolysis, acylamidase activity, and gluconate oxidation were investigated by using the methods of Elliott et al. (10). Temperature, $\mathrm{pH}, \mathrm{NaCl}$, and $\mathrm{FeCl}_{2}$ tolerance tests were all conducted with PCA $(0.2 \%$ agar) as the basal medium. Before a strain was considered positive for growth at a particular temperature, $\mathrm{pH}$, or salt concentration, it had to exhibit growth in each of three serial transfers in the same medium under the same incubation conditions. For the temperature tests, either water baths or heat blocks were used to ensure uniform and constant temperatures.

Numerical taxonomy. The results of the morphological and biochemical tests were analyzed by numerical taxonomy (41). The binary data were coded $(0$, negative; 1 , positive; 9 , not done or no growth) and placed into an $n-\times-t$ (character- $X$-operational taxonomic unit [OTU]) data matrix file; the resulting data file contained 82 characters (i.e., tests) and 22 OTUs. Similarity coefficients were calculated by using the simple matching $\left(S_{\mathrm{SM}}\right)$ and Jaccard $\left(S_{\mathrm{J}}\right)$ equations available in the PC-TAXAN numerical taxonomy program (release 2.0 ; University of Maryland Biotechnology Institute, University of Maryland System, College Park). Clustering was done by the unweighted pair group mathematical averaging (UPGMA) method, which is also available in PC-TAXAN.

DNA extraction and analysis. DNAs were extracted from 13 strains $([P]$. indigofera $19706^{\mathrm{T}}$ and ATCC 14036, strains JG3, JG5, JG6, JG7, JG9, JG10, JG11, JG12, JG13, JG15, and JG17, and Pseudomonas aeruginosa ATCC $10145^{\mathrm{T}}$ ) by the method of Marmur (29), modified as described previously (15). Each DNA was dialyzed at $4^{\circ} \mathrm{C}$, and at least three optical melting curve midpoints $\left(T_{m}\right)$ were determined for each DNA extract in $0.2 \times \mathrm{SSC}(1 \times \mathrm{SSC}$ is 0.15 $\mathrm{M} \mathrm{NaCl}$ plus $0.015 \mathrm{M}$ sodium citrate) with a model $2600-\mathrm{XY}$ spectrophotometer (Gilford, Oberlin, Ohio) by using DNA from ATCC $10145^{\mathrm{T}}$ as the reference $(\mathrm{G}+\mathrm{C}$ content, $67.0 \mathrm{~mol} \%)$. The results of the $T_{m}$ determinations were converted to $\mathrm{G}+\mathrm{C}$ contents (30) and mathematically averaged for each strain. The presence of plasmid DNA was investigated by using the method of Kado and Liu (19), as modified by Mach and Grimes (27), with strains JG3, JG5, JG6, JG7, JG9, JG10, JG11, JG12, JG13, JG14, JG15, JG16, and JG17 and $[P$.] indigofera ATCC $19706^{\mathrm{T}}$ and ATCC 14036. 
5S rRNA extraction and analysis. The $5 \mathrm{~S}$ rRNAs of $[P$.$] indigofera \mathrm{ATCC}$ $19706^{\mathrm{T}}$ and Chromobacterium violaceum ATCC $12472^{\mathrm{T}}$ were isolated by the phenol method and were purified by electrophoresis on a thiol-soluble acrylamide gel containing bis-acrylylcystamine (Bio-Rad Laboratories, Richmond Calif.) by using methods described by Hansen (16). The nucleotide base se quence of $3^{\prime}$ (and $5^{\prime}$ ) ${ }^{32} \mathrm{P}$-labeled 5S rRNA was determined by an expanded enzymatic method $(23,24)$. The terminal base was identified by autoradiography after exhaustive digestion (with nucleases $T_{2}$ and $P_{1}$ for the $3^{\prime}$ - and $5^{\prime}$-terminal nucleotides, respectively) of ${ }^{32} \mathrm{P}$-labeled $5 \mathrm{~S}$ rRNA, followed by resolution of the resulting monophosphates on polyethyleneimine-cellulose thin-layer plates by the thin-layer chromatography methods of Randerath and Randerath (38). See references 25 and 42 for further details.

16S rRNA extraction and analysis. Cell masses for five strains $([P$.$] indigofera$ ATCC $19706^{\mathrm{T}}$, JG3 [= ATCC 35906], JG7 [= ATCC 35907], JG15 [ = ATCC 35908 ], and JG17 [= ATCC 35909]) were generously provided by R. Gherna of the American Type Culture Collection. RNA was extracted from the cells by customary procedures $(50)$, and sequences were determined by the dideoxynucle otide chain termination method adapted for direct rRNA sequencing in which reverse transcriptase is used $(2,22)$. Synthesized strands were labeled by including ${ }^{35} \mathrm{~S}$ - $\alpha$-thio-dATP (2). A standard set of eubacterium-specific primers (48) was used to sequence the $16 \mathrm{~S}$ rRNAs. More than $95 \%$ of the sequence of the $[P$. indigofera type strain was determined. Only partial sequences $(\sim 540$ nucleotides $)$ of the remaining strains, which are all closely related to $[P$.$] indigofera ATCC$ $19706^{\mathrm{T}}$, were determined. For data alignment and analysis we used various functions of the Ribosomal Database Project server at the University of Illinois (28). The alignment chosen was obtained from the E-mail server by using its SUB_ALIGN function, the $\left[P\right.$.] indigofera ATCC $19706^{\mathrm{T}}$ sequence was placed into the alignment by using the server's ALIGN SEQUENCE function, and a maximum-likelihood tree was produced with the server's SUGGEST TREE function (35). Evolutionary distances were generated by using the Jukes-Cantor correction (18), as modified by Olsen (34a). A tree based on these distances was generated by using the least-squares additive algorithm of De Soete (5).

Pure-carbon-source studies. Single-carbon-source utilization was investigated by spot inoculating (model A400 multipoint inoculator; Denley, Sussex, England) faintly turbid suspensions $(0.85 \% \mathrm{NaCl})$ of each strain onto plates of minimal medium containing carbon sources at a concentration of $1 \%$ (wt/vol). The minimal medium contained (per liter of reagent grade water) $0.1 \mathrm{~g}$ of $\mathrm{MgSO}_{4}, 1.0 \mathrm{~g}$ of NaCl, $1.0 \mathrm{~g}$ of $\mathrm{NH}_{4} \mathrm{H}_{2} \mathrm{PO}_{4}, 1.0 \mathrm{~g}$ of $\mathrm{K}_{2} \mathrm{HPO}_{4}, 0.001 \mathrm{~g}$ of $\mathrm{FeSO}_{4}$, and $15 \mathrm{~g}$ of Noble agar.

Nucleotide sequence accession number. The GenBank accession number for the $16 \mathrm{~S}$ rRNA sequence of strain ATCC $19706^{\mathbf{T}}$ is U45995.

\section{RESULTS AND DISCUSSION}

Cellular and colonial morphology. $V$. indigofera gen. nov., comb. nov. and the other members of the genus Vogesella are gram-negative eubacteria that form rods (average dimensions, 0.5 by $3.5 \mu \mathrm{m}$ ) and occur primarily as individual bacilli, but also as pairs of rods and short chains; occasional vibrioid rods are also observed. When grown on the nitrogen-limiting agar $(2 \mathrm{~g}$ of $\mathrm{C}$ per liter and $0.02 \mathrm{~g}$ of $\mathrm{N}$ per liter) used for PHB analysis, most strains form filamentous rods and long chains. All of the Vogesella strains are motile by means of a single polar flagellum and exhibit very rapid darting or zig-zagging motility. When grown in nitrogen-limiting medium, cells stained with Sudan black B exhibit extensive PHB granule formation; cells grown on PCA have markedly less PHB deposition. Other types of inclusion bodies have not been detected.

The colors of the colonies formed by $V$. indigofera and the other Vogesella strains are striking; the colonies begin as translucent slightly yellowish colonies at early stages of growth (i.e., 16 to $20 \mathrm{~h}$ ), then assume a faint bluish hue $(24 \mathrm{~h})$, and finally become a very deep royal blue with a metallic copper-colored sheen ( 36 to $48 \mathrm{~h}$ ). Examination of metallic-blue colonies with a dissecting microscope revealed the presence of bluish crystals, which presumably are excess pigment that accumulates in the colonies. When a colony is removed from an agar plate, a blue imprint or stain is left in the agar, a phenomenon that has been described by other workers $(32,45)$. The colonies themselves are round, entire, raised, smooth, and shiny; they are approximately $1 \mathrm{~mm}$ in diameter (uncrowded growth) after $24 \mathrm{~h}$ and $2 \mathrm{~mm}$ in diameter after $48 \mathrm{~h}$ and reach a maximum diameter of ca. $10 \mathrm{~mm}$ after 1 to 2 weeks. Old colonies tend to have cream to yellowish edges and blue centers. On most agar media, the agar under and in the vicinity of growth becomes slightly straw yellow and may exhibit weak fluorescence (yellow-green) under shortwave UV light. The colonies formed by Vogesella strains did not resemble the colonies of any Pseudomonas sp., including Pseudomonas lemonnieri ATCC 12983 (45). Media which have been found to support abundant blue pigmentation include PCA, Thayer-Martin agar, chocolate agar, blood agar, Pseudomonas $\mathrm{F}$ agar, and, especially, chalk agar (45). Media which enhanced blue pigmentation were corn oil agar and PCA enriched with $1 \%$ (vol/vol) glycerol; the latter medium yielded colonies with a metallic copper sheen and a reddish hue. It was observed during the $\mathrm{pH}$ tolerance tests that slightly acid conditions (ca. $\mathrm{pH}$ 6.5) favored pigment production on PCA. R2A agar (Difco) did not support good growth of Vogesella strains, and pigment production was abnormal for all of the strains tested on this medium except the $P$. aeruginosa and Pseudomonas putida strains. When grown on PCA enriched with $1 \%$ (vol/vol) Tween 80 , all of the Vogesella strains formed a purple pigment that was visually indistinguishable from the pigment of Chromobacterium violaceum ATCC $12472^{\mathrm{T}}$ and Janthinobacterium lividum ATCC $12473^{\mathrm{T}}$ grown on the same medium. Several pure carbon sources also supported blue pigmentation of the Vogesella strains, especially putrescine, proline, histidine, and $\mathrm{L}$ - and $\mathrm{D}$-alanine.

Pyridine extracts of $[P$.$] indigofera (strain ATCC 19706^{\mathrm{T}}$ ) and " $P$. aenacaerulea" (strain JG3) were found to be identical (19a) based on the results of an infrared spectral analysis (from 850 to $4,000 \mathrm{~cm}^{-1}$ ) of the extracts. The two spectra were similar to the spectrum published by Kuhn et al. (21), and they also resembled spectra published by Norton and Jones (34). Extraction of chalk agar growth with $1 \mathrm{~N} \mathrm{NaOH}$ produced an immediate blue-purple liquid that faded to yellow, which is also consistent with the observation of Kuhn et al. (21). In addition, by using sonication and the cell envelope dissection technique developed by Forsberg et al. (12) and modified by Rayman and MacLeod (39), it was shown that the blue pigment was localized within the cytoplasmic membrane (19a). Other bacteria (Arthrobacter spp., Corynebacterium insidiosum, and Erwinia chrysanthemi) also form the same blue pigment, which has been identified as indigoidine $\left(\mathrm{C}_{10} \mathrm{H}_{8} \mathrm{~N}_{4} \mathrm{O}_{4}\right.$ or 5,5'diamino-4,4'-dihydroxy-3,3'-diazadiphenoquinone-[2,2']), a water-insoluble bipyridyl compound (21). In E. chrysanthemi, indigoidine production is easily lost and the locus for indigoidine is chromosomal and linked to the locus for arginine synthesis (3). Indigoidine production is a stable attribute of the strains examined in the present study.

Metabolic characteristics and cluster analysis. The $15 \mathrm{Vo}$ gesella strains displayed a metabolism typical of many nonfermentative gram-negative rods (Table 2 ). Specifically, they were capable of catabolizing a few monosaccharides under aerobic conditions, but not under low-oxygen conditions (i.e., in oilcovered oxidation-fermentation [OF] tubes). Starch was not hydrolyzed, and the strains did not appear to be lipolytic (Table 2). In addition, neither pectin nor sugars associated with pectin (i.e., arabinose and galactose) were metabolized. The Vogesella strains did not appear to derive nutrition from proteins, as shown by their inability to hydrolyze casein and gelatin; however, several amino acids and peptides were utilized, although they were not decarboxylated. Unlike most pseudomonads, which catabolize tryptophan by first cleaving the pyrrole ring, all of the Vogesella strains tested produced indole; in fact, agar plate cultures containing peptides high in tryptophan always smelled strongly of this heterocyclic compound. Ensley et al. (11) proposed a pathway for synthesis of indigo from indole; however, the bipyridyl pigment indigoidine is structurally distinct from indigo. All of the Vogesella strains were ca- 
TABLE 2. Characteristics of the Vogesella and reference strains examined ${ }^{a}$

\begin{tabular}{|c|c|c|c|c|c|c|c|c|c|}
\hline Characteristic & 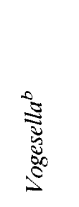 & 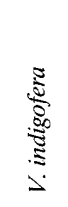 & 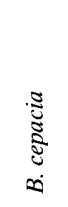 & 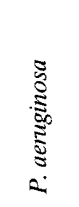 & 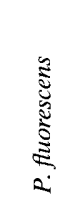 & $\frac{\mathbb{Z}}{\mathbb{\Xi}}$ & 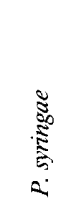 & 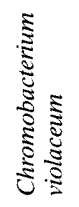 & $\begin{array}{l}\Xi \\
\stackrel{\Xi}{\Xi} \\
\stackrel{\Xi}{\Xi} \\
-\end{array}$ \\
\hline Indigoidine & 100 & $+^{c}$ & - & - & - & - & - & - & - \\
\hline Pyoverdin & 0 & - & - & + & + & + & + & - & - \\
\hline Violacein & 0 & - & - & - & - & - & - & + & + \\
\hline Fluorescence $^{d}$ & 100 & + & - & + & + & + & + & - & - \\
\hline Oxidase & 100 & + & + & + & + & + & - & + & + \\
\hline Catalase & 100 & + & + & + & + & + & + & + & + \\
\hline Swarming & 0 & - & - & + & - & - & - & - & - \\
\hline Polar flagella & 100 & + & + & + & + & + & + & + & + \\
\hline PHB granules & 100 & + & ND & - & - & - & ND & + & + \\
\hline Alpha-hemolysis & 100 & + & ND & - & - & ND & ND & - & - \\
\hline Beta-hemolysis & 0 & - & ND & + & - & ND & ND & - & - \\
\hline \multicolumn{10}{|l|}{ Growth in the presence of: } \\
\hline $0 \% \mathrm{NaCl}$ & 100 & + & + & + & + & + & + & + & + \\
\hline $1 \% \mathrm{NaCl}$ & 100 & + & + & + & + & + & + & + & + \\
\hline $2 \% \mathrm{NaCl}$ & 0 & - & ND & - & - & - & ND & - & - \\
\hline \multicolumn{10}{|l|}{ Growth at: } \\
\hline $2^{\circ} \mathrm{C}$ & 0 & - & ND & - & + & ND & ND & - & + \\
\hline $4^{\circ} \mathrm{C}$ & 100 & + & ND & - & + & ND & ND & - & + \\
\hline $37^{\circ} \mathrm{C}$ & 100 & + & $\mathrm{ND}$ & + & - & ND & ND & + & - \\
\hline $40^{\circ} \mathrm{C}$ & 30 & + & ND & + & - & ND & ND & + & - \\
\hline $\mathrm{pH} 4.0$ & 0 & - & ND & - & - & ND & ND & - & - \\
\hline pH 6.2 & 100 & + & + & + & + & + & + & + & + \\
\hline pH 8.6 & 90 & + & ND & + & + & ND & ND & ND & ND \\
\hline Indole & 100 & + & - & - & - & - & - & - & - \\
\hline Methyl red & 0 & - & - & - & - & - & - & - & - \\
\hline Voges-Proskauer & 0 & - & - & - & - & - & - & - & - \\
\hline Citrate & 0 & - & + & + & + & + & + & + & + \\
\hline $\mathrm{H}_{2} \mathrm{~S}$ & 0 & - & + & - & - & - & - & - & - \\
\hline Nitrate reduction & 100 & + & - & + & - & + & - & + & + \\
\hline Gas produced from nitrate & 100 & + & - & + & - & - & - & - & - \\
\hline \multicolumn{10}{|l|}{ Decarboxylases } \\
\hline Arginine & 0 & - & - & - & - & + & - & + & - \\
\hline Lysine & 0 & - & - & - & - & - & - & - & - \\
\hline Ornithine & 0 & - & - & - & - & - & - & - & - \\
\hline Tryptophan & 0 & - & - & - & - & - & - & - & - \\
\hline Phenylalanine deaminase & 0 & - & - & - & - & - & - & - & - \\
\hline Acylamidase & 0 & - & ND & + & - & ND & ND & - & - \\
\hline Urease & 0 & - & - & - & - & - & - & - & - \\
\hline Malonate & 0 & - & ND & + & + & ND & ND & - & + \\
\hline Gluconate & 0 & - & ND & + & - & ND & ND & - & - \\
\hline Esculin & 0 & - & ND & - & - & ND & ND & - & + \\
\hline $\mathrm{ONPG}^{e}$ & 0 & - & ND & - & - & ND & ND & $\mathrm{ND}$ & ND \\
\hline DNase & 100 & + & + & + & + & + & + & + & + \\
\hline Gelatinase & 0 & - & ND & + & + & - & ND & + & - \\
\hline Caseinase & 0 & - & + & + & + & - & + & + & - \\
\hline Chitinase & 0 & - & ND & - & - & ND & ND & - & ND \\
\hline Pectinase & 0 & - & + & - & ND & - & - & - & ND \\
\hline Starch & 0 & - & - & - & - & - & - & - & - \\
\hline Tween 80 & 0 & - & $\mathrm{ND}$ & + & + & ND & ND & + & + \\
\hline Corn oil & 0 & - & ND & - & - & ND & ND & - & - \\
\hline \multicolumn{10}{|l|}{ OF utilization of sugars } \\
\hline Arabinose & $0 / 0^{f}$ & $-1-$ & ND & $+1-$ & $+1-$ & ND & ND & $-1-$ & $+1-$ \\
\hline Fructose & $73 / 0$ & $-1-$ & $-1-$ & $+1-$ & $+1-$ & $+1-$ & $+1-$ & $+1-$ & ND \\
\hline Galactose & $20 / 0$ & $-1-$ & $+1-$ & $+1-$ & $+1-$ & $+1-$ & $+1-$ & $-1-$ & $+1-$ \\
\hline Glucose & $80 / 0$ & $-1-$ & $+1-$ & $+1-$ & $+1-$ & $+1-$ & $-1-$ & $+1-$ & $+1-$ \\
\hline Glycerol & $87 / 0$ & $+1-$ & $-1-$ & $+1-$ & $+1-$ & $+1-$ & $+1-$ & $-1-$ & $+1-$ \\
\hline Inositol & $40 / 0$ & $+1-$ & $-1-$ & $-1-$ & $+1-$ & $-1-$ & $+1-$ & $-1-$ & $-1-$ \\
\hline Sucrose & $60 / 0$ & $-1-$ & $+1-$ & $-1-$ & $+1-$ & $-1-$ & $+1-$ & $+1+$ & $+1-$ \\
\hline Xylose & $0 / 0$ & $-1-$ & ND & $+1-$ & $+1-$ & ND & $\mathrm{ND}$ & $-1-$ & $+1-$ \\
\hline \multicolumn{10}{|c|}{ Utilization of single carbon sources } \\
\hline Ethanol & 80 & + & ND & + & - & + & ND & ND & ND \\
\hline D-Glycerol & 90 & + & $\mathrm{ND}$ & + & + & + & ND & ND & ND \\
\hline 1-Propanol & 40 & - & ND & + & - & + & ND & ND & ND \\
\hline
\end{tabular}




\begin{tabular}{|c|c|c|c|c|c|c|c|c|c|}
\hline Characteristic & 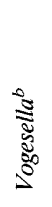 & 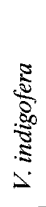 & 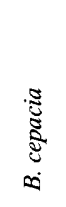 & 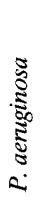 & ${ }_{2}^{\stackrel{5}{3}}$ & $\frac{\mathbb{Z}}{\stackrel{\Xi}{\Xi}}$ & 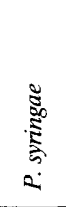 & 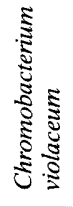 & 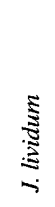 \\
\hline D-Alanine & 80 & + & $\mathrm{ND}$ & + & + & + & ND & ND & ND \\
\hline L-Alanine & 80 & + & ND & + & + & + & ND & ND & ND \\
\hline L-Arginine & 90 & + & ND & + & + & + & ND & ND & $\mathrm{ND}$ \\
\hline L-Histidine & 90 & + & ND & + & + & + & ND & ND & ND \\
\hline L-Ornithine & 90 & + & ND & + & + & + & ND & $\mathrm{ND}$ & ND \\
\hline L-Proline & 90 & + & $\mathrm{ND}$ & + & + & + & ND & ND & ND \\
\hline L-Tryptophan & 60 & + & ND & + & + & + & ND & ND & ND \\
\hline D-Fructose & 80 & + & ND & + & + & + & ND & $\mathrm{ND}$ & ND \\
\hline D-Glucose & 90 & + & ND & + & + & + & ND & ND & ND \\
\hline$\gamma$-Aminobutyrate & 80 & + & ND & + & + & + & ND & ND & ND \\
\hline$\Delta$-Aminovalerate & 70 & + & ND & + & + & + & ND & ND & ND \\
\hline Fumarate & 90 & + & ND & + & + & + & ND & ND & $\mathrm{ND}$ \\
\hline Propionate & 0 & - & ND & + & + & + & ND & ND & ND \\
\hline Putrescine & 90 & + & ND & + & + & + & ND & ND & ND \\
\hline
\end{tabular}

"A total of 15 Vogesella strains, including strain ATCC $19706^{\mathrm{T}}$, were tested. Only the type strain of each of the other taxa was tested (see Table 1).

${ }^{b}$ The values are the percentages of the 15 strains tested that gave a positive reaction.

$c+$, positive reaction; - negative reaction; ND, not done.

${ }^{d}$ Fluorescence on chalk agar (45) with short-wavelength UV illumination. All Vogesella strains exhibited very weak fluorescence.

e ONPG, $o$-nitrophenyl- $\beta$-D-galactopyranoside.

${ }^{f}$ Result for open reaction/result for covered reaction.

${ }^{g}$ Only 10 Vogesella strains (ATCC $19706^{\mathrm{T}}$, JG3, JG5, JG6, JG7, JG9, JG10, JG11, JG12, JG13) were used in the single-carbon-source utilization tests.

pable of denitrification, and all but one (JG9) utilized most of the single carbon sources tested. In general, there are few major metabolic differences between the two $[P$.] indigofera reference strains and the 13 isolates which we studied (Table 2).

The results of the cluster analysis of similarity coefficients $\left(S_{\mathrm{SM}}\right)$ calculated for the 82 morphological and biochemical characteristics of the 22 OTUs studied are shown in Fig. 1. The 15 Vogesella strains, including type strain ATCC $19706^{\mathrm{T}}$ of $V$. indigofera, clustered tightly at $90.0 \%$ similarity $\left(S_{\mathrm{SM}}\right)$ and were not closely related to any other strains or clusters. Phenotypically, the Vogesella strains were most closely related to Burkholderia cepacia ATCC $25416^{\mathrm{T}}$, J. lividum ATCC $12437^{\mathrm{T}}$, and the Pseudomonas type strains tested $\left(S_{\mathrm{SM}}, 73.6 \%\right)$ and only distantly related to Chromobacterium violaceum ATCC $12472^{\mathrm{T}}$ $\left(S_{\mathrm{SM}}, 68.6 \%\right)$. Interestingly, the fluorescent pseudomonads clustered at an $S_{\mathrm{SM}}$ value of $83.9 \%$; this phenon represents the Pseudomonas fluorescens rRNA branch of De Vos et al. (7) and the fluorescent species belonging to rRNA group I of Palleroni (36).

When the results of the 17 pure-carbon-source tests (Table 2) were removed from the data matrix and the UPGMA cluster analysis of $S_{\mathrm{SM}}$ similarity coefficients was replotted, few changes resulted (data not shown). The 15 Vogesella strains clustered at an $S_{\mathrm{SM}}$ value of $91.6 \%$ and grouped with $B$. cepacia, J. lividum, and the Pseudomonas species at an $S_{\mathrm{SM}}$ value of $73.5 \%$. The fluorescent pseudomonads clustered together at an $S_{\mathrm{SM}}$ value of $83.4 \%$, and Chromobacterium violaceum was related to all of the other OTUs at an $S_{\mathrm{SM}}$ value of $68.7 \%$. A cluster analysis of the similarity coefficients calculated by using the $S_{\mathrm{J}}$ equation resulted in identical relative relationships, but lower levels of similarity (data not shown). We concluded that the morphological and biochemical tests that were not done (Table 2) had little effect on the outcome of the numerical analysis.

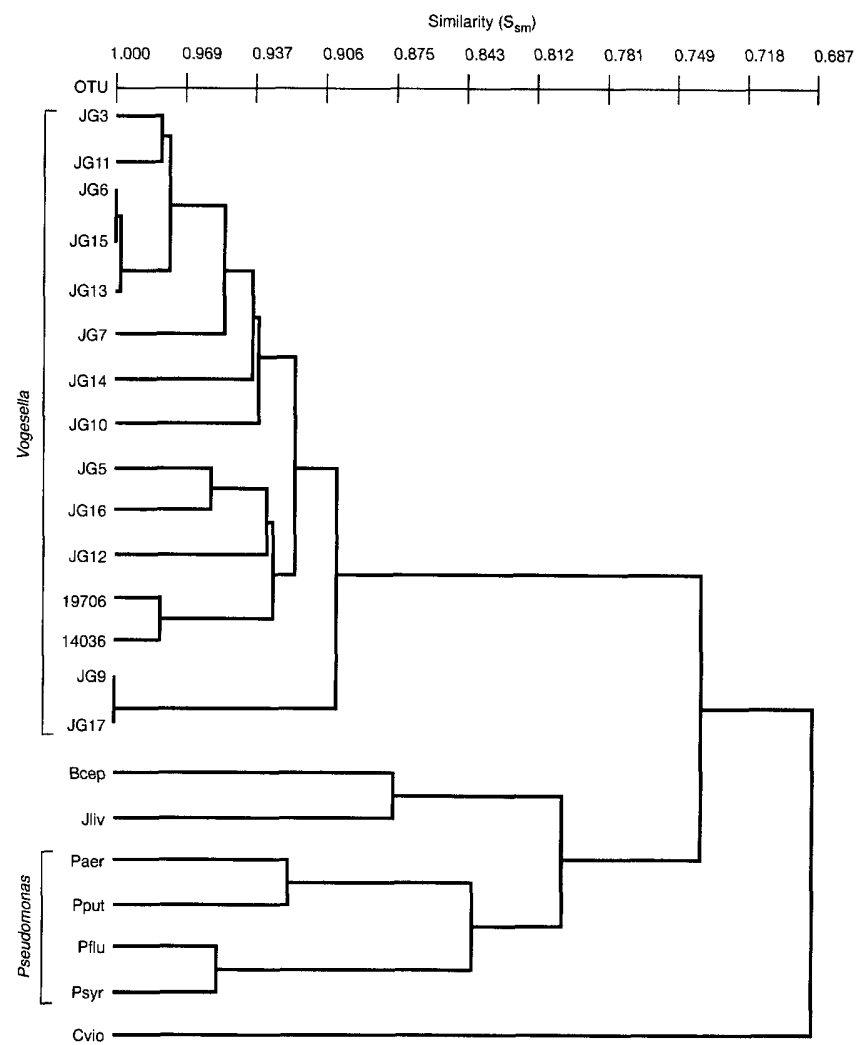

FIG. 1. Dendrogram, based on a UPGMA cluster analysis of the $S_{\mathrm{SM}}$ similarity coefficients of the 22 strains listed in Table 1 and the 82 tests performed (the 80 tests listed in Table 2 [each OF sugar test was scored twice], Gram reaction, and rod-shaped morphology). Abbreviations: Bcep, B. cepacia, Jliv, J. lividum; Paer, P. aenuginosa; Pput, P. putida; Pflu, P. fluorescens; Psyr, Pseudomonas syringae; Cvio, Chromobacterium violaceum. 
TABLE 3. Average $\mathrm{G}+\mathrm{C}$ contents of Vogesella strains

\begin{tabular}{|c|c|}
\hline Strain & $\begin{array}{c}\mathrm{G}+\mathrm{C} \text { content } \\
\quad(\mathrm{mol} \%)^{a}\end{array}$ \\
\hline $\begin{array}{l}\text { JG3 }(=\text { ATCC } \\
\text { JG5 } \\
\text { JG6... } \\
\text { JG7 }(=\text { ATCC } \\
\text { JG9 } \\
\text { JG10 } \\
\text { JG11 } \\
\text { JG12 } \\
\text { JG13 } \\
\text { JG15 (= ATC } \\
\text { JG17 (= ATC } \\
\text { ATCC } 19706{ }^{\mathrm{T}} \text {. } \\
\text { ATCC 14036 ... } \\
\text { Mean (SD) } . . . .\end{array}$ & $\begin{array}{l}\ldots 66.9 \\
\ldots 667.3 \\
\ldots .67 .6 \\
\ldots .67 .6 \\
\ldots .68 .4 \\
\ldots .66 .2 \\
\ldots .66 .2 \\
\ldots .68 .5 \\
\ldots .66 .8 \\
\ldots .667 .6 \\
\ldots .66 .3 \\
\ldots .667 .6 \\
\ldots .67 .6(0.9)\end{array}$ \\
\hline
\end{tabular}

${ }^{a}$ As determined by thermal denaturation $\left(T_{m}\right)$. P. aeruginosa ATCC $10145^{\mathbf{T}}$ was used as the reference $(\mathrm{G}+\mathrm{C}$ content, $67.0 \mathrm{~mol} \%)$.

DNA analysis. The results of the thermal denaturation $\left(T_{m}\right)$ studies of the Vogesella strains are presented in Table 3 . The overall average $\mathrm{G}+\mathrm{C}$ content (based on 70 melts) was 67.6 mol\%, and the standard deviation was $0.9 \mathrm{~mol} \%$. The value determined for $V$. indigofera ATCC $19706^{\mathrm{T}}$ was $65.4 \mathrm{~mol} \%$ (standard deviation, $0.2 \mathrm{~mol} \%$ ). These values were somewhat higher than the value cited by Palleroni (36) (64.3 mol\%) and the values reported by Kolar (19a). The values reported for section I Pseudomonas species (rRNA superfamily I) ranged from 59.4 to $68 \mathrm{~mol} \% \mathrm{G}+\mathrm{C}(36)$, with $P$. aeruginosa strains having the highest values. Chromobacterium $\mathrm{G}+\mathrm{C}$ contents have been reported to range from 65.2 to $67.2 \mathrm{~mol} \%$, Janthinobacterium $\mathrm{G}+\mathrm{C}$ contents range from 61.2 to $66.1 \mathrm{~mol} \%$, and the values that have been reported for $B$. cepacia are 67.5 mol\% (4) and $66.6 \mathrm{~mol} \%$ (51). Plasmids were not observed in any of the Vogesella strains under the extraction and detection conditions employed in this study.

5S rRNA analysis. Results of the 5S rRNA studies are presented for two reasons. These studies were initiated in the early $1980 \mathrm{~s}$, before $16 \mathrm{~S}$ rRNA sequencing techniques and the associated database were available. In addition, $5 \mathrm{~S}$ rRNA analysis continues to be a useful tool for differentiating strains $(26,46)$. A comparison of the $5 \mathrm{~S}$ rRNA nucleotide base sequence of $V$. indigofera ATCC $19706^{\mathrm{T}}$ with published sequences of other eubacterial species indicated that $V$. indigofera was phylogenetically distinct from the genus Pseudomonas sensu stricto (6), as represented by $P$. aeruginosa, $P$. fluorescens, and $P$. putida. Species belonging to the phylogenetically valid genus Pseudomonas are members of rRNA superfamily I (6), which constitutes a large portion of the gamma subdivision of the Proteobacteria $(33,43)$. De Vos et al. (7) have recommended that only the $P$. fluorescens rRNA branch be retained within the genus Pseudomonas sensu stricto. However, the sequence of the $5 \mathrm{~S}$ rRNA of $V$. indigofera is typical of sequences of members of rRNA superfamily III (beta subdivision of the Proteobacteria), which includes the genera Neisseria, Chromobacterium, and Janthinobacterium, some members of the Pseudomonas solanacearum complex (6) now reclassified as several Burkholderia (14) and Ralstonia (51) species, and the genera Aquaspirillum and Prolinoborus (37). Finally, the $V$. indigofera sequence exhibits substantial homology with the $5 \mathrm{~S}$ rRNA sequence of $B$. cepacia (42). Figure 2 shows a rooted tree that placed $V$. indigofera ATCC $19706^{\mathrm{T}}$ on a branch with other members of the beta subdivision of the Proteobacteria, and the taxon most closely related to $V$. indigofera was Chromobacterium violaceum.

16S rRNA analysis. All of the strains examined for $16 \mathrm{~S}$ rRNA similarity were found to be closely related. Strains ATCC 35906 and ATCC 35907 (oxidation pond and Mississippi River isolates) were indistinguishable from the type strain (ATCC 19706, the only strain whose complete sequence was determined), while strains ATCC 35908 and ATCC 35909 (Potomac River isolates) differed from the type strain at only two and three positions, respectively (i.e., roughly a $0.5 \%$ difference). A phylogenetic tree produced by a maximum-likelihood analysis of representative species belonging to the beta subdivision of the Proteobacteria (see Materials and Methods) is shown in Fig. 3. An evolutionary distance tree (see Materials and Methods) had in essence the same branching pattern as the tree shown in Fig. 3 (data not shown). The conclusion which we reached was that $V$. $\left[P\right.$.] indigofera ATCC $19706^{\mathrm{T}}$ and the other Vogesella strains are close relatives of Chromobacterium violaceum, but sufficiently distinct to warrant placement in a new genus.

The results of the phenotypic (Table 2 and Fig. 1) and genotypic (Table 3 and Fig. 2 and 3 ) analyses reinforced each other and the conclusion that $[P$.] indigofera should be reclassified. Phenotypically, the 15 Vogesella strains closely resembled members of the genus Pseudomonas sensu stricto and $B$. $\left[P\right.$.] cepacia $\left(S_{\mathrm{SM}}, 73.6 \%\right)$, which is the reason that all of these organisms were initially classified with the aerobic pseudomonads (44). Both Vogesella spp. and Pseudomonas spp. are gram-negative, polarly flagellated rods that respire a wide variety of organic compounds by using oxygen as the terminal acceptor of electrons. Nitrate is reduced to nitrite by many pseudomonads and is reduced to $\mathrm{N}_{2}$ by $P$. aeruginosa (Table 2); all of the Vogesella strains tested also reduced nitrate to $\mathrm{N}_{2}$ (Table 2). Like the pseudomonads, the Vogesella strains tested were oxidase and catalase positive and did not require complex

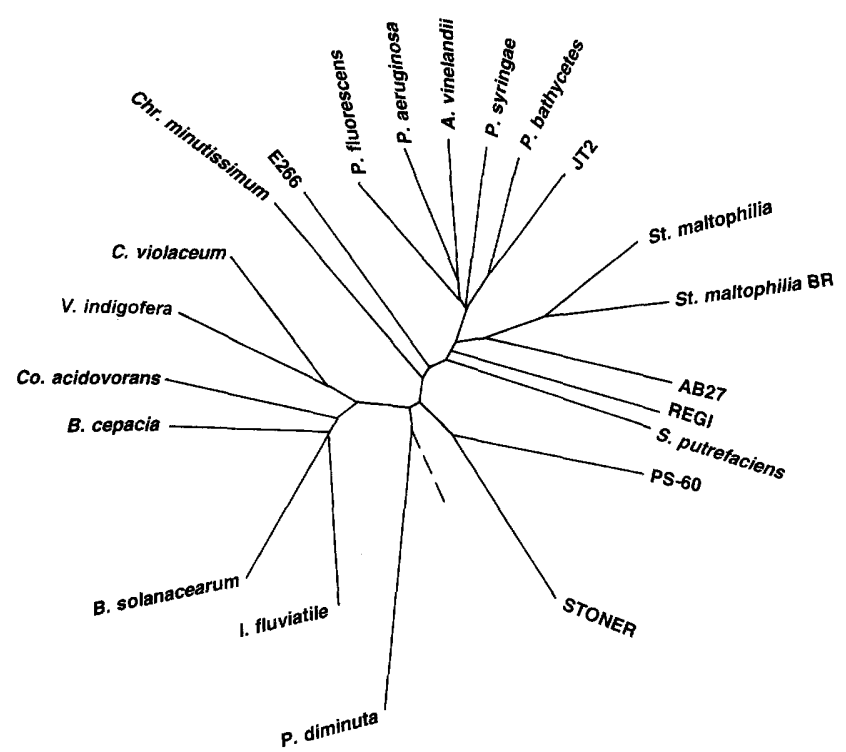

FIG. 2. Evolutionary distances derived from differences in the 5S rRNA sequences of 22 bacterial species. The rooted tree was generated by using the KITSCH routine of PHYLIP (11a, 23). Abbreviations: STONER, estuarine isolate Stoner; PS-60, Pseudomonas sp. strain ATCC 31461; REGI, Odontella regia symbiont (22); AB27, Xanthomonas sp. strain AB27; JT2, Pseudomonas sp. strain JT2. E266, estuarine pseudomonad strain E266; A., Azotobacter; P., Pseudomonas; St., Stenotrophomonas; I., Iodobacter; B., Burkholderia; Co., Comamonas; V., Vogesella; $C$., Chromobacterium; Chr., Chromatium. 


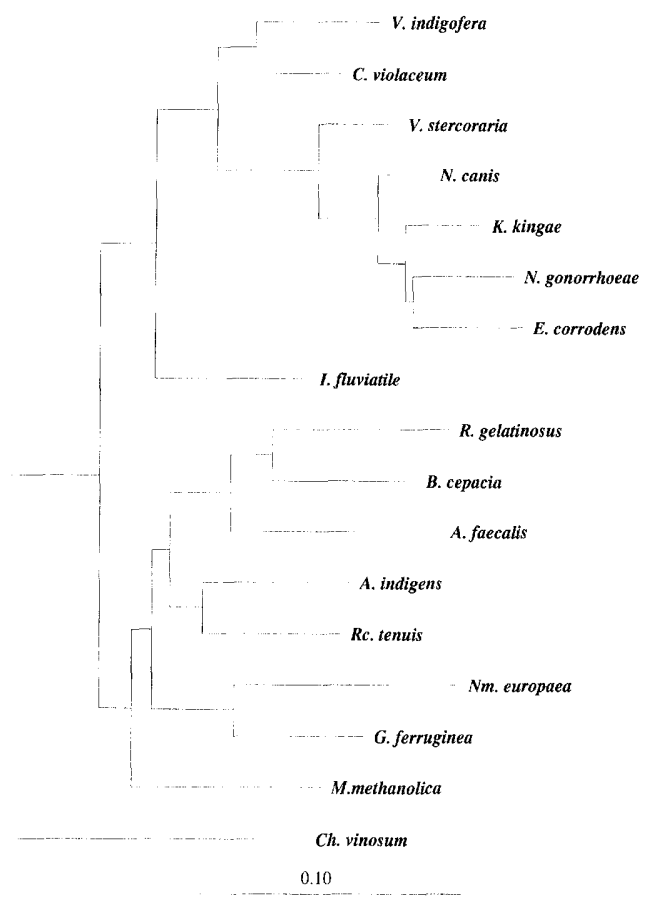

FIG. 3. Maximum-likelihood tree for a representative sample of members of the beta subdivision of the Proteobacteria (see Materials and Methods). Chromatium vinosum ATCC 17899 was used as the outgroup which defines the root. Scale bar $=10$ differences per 100 nucleotides. Abbreviations: $V$. indigofera, Vogesella indigofera; $C$., Chromobacterium; V. stercoraria, Vitreoscilla stercoraria: N., Neisseria; K., Kingella; E., Eikenella; I., Iodobacter, R., Rubrivivax; B., Burkholderia; A., Alcaligenes; Rc., Rhodocyclus; Nm., Nitrosomonas; G., Gallionella; M., Methylomonas; Ch., Chromatium.

growth factors. Chromobacterium violaceum also has these general traits, but differs by fermenting certain sugars and by decarboxylating arginine, among other things. Nitrate was reduced to nongaseous products by Chromobacterium violaceum, which is consistent with the observation of Bazylinski et al. (1a). While these differences are not great, there is only $68.6 \%$ similarity $\left(S_{\mathrm{SM}}\right)$ between Chromobacterium violaceum and the other 21 OTUs tested in this study (Fig. 1). Analyses of the 5S rRNA and 16S rRNA nucleotide base sequences of $[P$.] indigofera ATCC $19706^{\mathrm{T}}$ placed this strain in the beta subdivision of the Proteobacteria and revealed a close relationship with Chromobacterium violaceum ATCC $12472^{\mathrm{T}}$. These findings prompted us to recommend that $[P$.] indigofera be reclassified. All strains of the indigoidine-producing pseudomonads that were tested are closely related to one another, based on both phenotypic and genotypic evidence, and so are placed in a new genus, the genus Vogesella.

The composition of the beta subdivision of the Proteobacteria is undergoing substantial change, as early classifications based solely on phenotypic similarities are yielding to polyphasic approaches $(4,14,37,43,51)$. The results of this study provided evidence for including yet another new genus in the beta subdivision of the Proteobacteria. Perusal of the trees prepared by Gillis et al. (14) and Pot et al. (37) reveals that many members of this phylogenetic group share key phenotypic characteristics and that many were previously classified in the genus Pseudomonas. We recommend that the genus Vogesella also be included in this group, and we encourage other investigators to include the $16 \mathrm{~S}$ rRNA sequence of $V$. indigofera in their comparative analyses. Further classification of the Vogesella strains must await DNA-DNA hybridization studies.
Description of Vogesella gen. nov. Vogesella (Vo.ges.el'la. German proper name Voges; M.L. dim. ending -ella; M.L. fem. n. Vogesella, named for Otto Voges to honor his original isolation of [Bacillus indigoferus] on gelatin plates inoculated with tap water from the central water supply system in Kiel, Germany, in 1893 [47]). Gram-negative, rod-shaped eubacteria. The average cell dimensions are 0.5 by $3.5 \mu \mathrm{m}$. Cells occur primarily as individual bacilli, but also as pairs of rods and short chains; occasional vibrioid rods are also observed. When grown on nitrogen-limiting agar, most strains form filamentous rods and long chains, and there is evidence of extensive PHB granule formation; cells grown on PCA have markedly less PHB deposition. Other types of inclusion bodies have not been detected. Motile by means of a single polar flagellum; the cells exhibit very rapid darting or zig-zagging motility. The colors of colonies formed by Vogesella strains are striking; the colonies begin as translucent slightly yellowish colonies at early stages of growth (i.e., 16 to $20 \mathrm{~h}$ ), then assume a faint bluish hue (24 $\mathrm{h}$ ), and finally become a very deep royal blue with a metallic copper-colored sheen ( 36 to $48 \mathrm{~h}$ ). The basis for this blue color is indigoidine $\left(\mathrm{C}_{10} \mathrm{H}_{8} \mathrm{~N}_{4} \mathrm{O}_{4}\right.$ or 5,5'-diamino-4,4'-dihydroxy$3,3^{\prime}$-diazadiphenoquinone- $\left.\left[2,2^{\prime}\right]\right)$. Vogesella strains are nonfermentative; they catabolize a few monosaccharides under aerobic conditions, but not under low-oxygen conditions. Starch is not hydrolyzed, and neither pectin nor sugars associated with pectin (i.e., arabinose and galactose) are metabolized. Vogesella strains are not lipolytic and are not able to hydrolyze casein and gelatin; several amino acids and peptides are utilized, although they are not decarboxylated. Indole is produced from tryptophan catabolism, and Vogesella strains are capable of denitrification. Citrate is utilized, and a wide variety of single carbon sources support growth. Thermal denaturation $\left(T_{m}\right)$ studies (based on 70 melts) of Vogesella DNA have shown that the $\mathrm{G}+\mathrm{C}$ content range for the genus is 65.4 to $68.8 \mathrm{~mol} \%$. The results of analyses of ribonucleotides (5S and $16 \mathrm{~S}$ rRNAs) place Vogesella on a branch with other members of the beta subdivision of the Proteobacteria, closely related to the genus Chromobacterium. Four Vogesella strains isolated in this study have been deposited in the American Type Culture Collection (ATCC 35906, ATCC 35907, ATCC 35908, and ATCC 35909). The type species is $V$. indigofera.

Description of Vogesella indigofera gen. nov., comb. nov. Vogesella indigofera (in.di.go'fe.ra. Fr. indigo, the dye indigo [from India]; L. suff. -fer, from L. v. fero, to bear; M.L. adj. indigofera, bearing indigo) is a gram-negative, rod-shaped eubacterium whose average dimensions are 0.5 by $3.5 \mu \mathrm{m}$. The cells occur primarily as individual bacilli, but they also occur as pairs of rods and short chains; occasional vibrioid rods are also observed. When the organism is grown on nitrogen-limiting agar, filamentous rods and long chains are formed, and there is evidence of extensive PHB granule formation; cells grown on PCA have markedly less PHB deposition. Other types of inclusion bodies have not been detected. $V$. indigofera is motile by means of a single polar flagellum and exhibits very rapid darting or zig-zagging motility. The colors of colonies formed by $V$. indigofera are striking; the colonies begin as translucent slightly yellowish colonies at early stages of growth (i.e., 16 to $20 \mathrm{~h}$ ), then assume a faint bluish hue ( $24 \mathrm{~h})$, and finally become a very deep royal blue with a metallic copper-colored sheen (36 to $48 \mathrm{~h}$ ). The basis for this blue color is indigoidine $\left(\mathrm{C}_{10} \mathrm{H}_{8} \mathrm{~N}_{4} \mathrm{O}_{4}\right.$ or 5,5'-diamino-4,4'-dihydroxy-3,3'-diazadiphenoquinone- $\left.\left[2,2^{\prime}\right]\right)$. $V$. indigofera is nonfermentative; it catabolizes a few monosaccharides under aerobic conditions, but not under low-oxygen conditions. Starch is not hydrolyzed, and neither pectin nor sugars associated with pectin (i.e., arabinose and galactose) are metabolized. $V$. indigofera is not lipolytic, 
and it is not able to hydrolyze casein and gelatin; several amino acids and peptides are utilized, although they are not decarboxylated. Indole is produced from tryptophan catabolism, and $V$. indigofera is capable of denitrification. Citrate is utilized, and a wide variety of single carbon sources support growth. Thermal denaturation $\left(T_{m}\right)$ studies of $V$. indigofera have shown that the mean $\mathrm{G}+\mathrm{C}$ content (based on six melts) is $65.4 \mathrm{~mol} \%$ (standard deviation, $0.2 \mathrm{~mol} \%$ ). The results of analyses of ribonucleotides (5S and $16 \mathrm{~S}$ rRNAs) place $V$. indigofera on a branch with other members of the beta subdivision of the Proteobacteria, closely related to the genus Chromobacterium. The type strain is $V$. indigofera ATCC 19706.

\section{ACKNOWLEDGMENTS}

We are grateful to Jackie Beaver, Eileen Curry, and Heather Hall for technical assistance. William Chesbro provided a helpful, critical review of the manuscript; Robert Gherna provided assistance with the reference strains; and Ludwig Feinendegen translated reference 47 and provided biographical information on Otto Voges.

\section{REFERENCES}

1. Austin, B., and R. R. Colwell. Unpublished data

1a.Bazylinski, D. A., E. Palome, N. A. Blakemore, and R. P. Blakemore. 1986 Denitrification by Chromobacterium violaceum. Appl. Environ. Microbiol. 52:696-699.

2. Biggin, M. D., T. J. Gibson, and G. F. Hong. 1983. Buffer gradient gels and $\left.{ }^{*}[35\}^{*}\right] \mathrm{S}$ label as an aid to rapid DNA sequence determination. Proc. Natl. Acad. Sci. USA 80:3963-3965.

3. Chatterjee, A. K., and M. A. Brown. 1981. Chromosomal location of a gene (idg) that specifies production of the blue pigment indigoidine in Erwinia chrysanthemi. Curr. Microbiol. 6:269-273.

4. De Ley, J., P. Segers, and M. Gillis. 1978. Intra- and intergeneric similarities of Chromobacterium and Janthinobacterium ribosomal ribonucleic acid cistrons. Int. J. Syst. Bacteriol. 28:154-168.

5. De Soete, G. 1983. A least squares algorithm for fitting additive trees to proximity data. Psychometrika 48:621-626.

6. De Vos, P., and J. De Ley. 1983. Intra- and intergeneric similarities of Pseudomonas and Xanthomonas ribosomal ribonucleic acid cistrons. Int. J. Syst. Bacteriol. 33:487-509.

7. De Vos, P., A. Van Landschoot, P. Segers, R. Tytgat, M. Gillis, M. Bauwens, R. Rossau, M. Goor, B. Pot, K. Kersters, P. Lizzaraga, and J. De Ley. 1989. Genotypic relationships and taxonomic localization of unclassified Pseudomonas and Pseudomonas-like strains by deoxyribonucleic acid-ribosomal ribonucleic acid hybridizations. Int. J. Syst. Bacteriol. 39:35-49.

8. Edwards, P. R., and W. H. Ewing. 1972. Identification of Enterobacteriaceae. Burgess Publishing Co., Minneapolis, Minn.

9. Elazari-Volcani, B. 1939. On Pseudomonas indigofera (Voges) Migula and its pigment. Arch. Mikrobiol. 10:343-358.

10. Elliott, T. B., G. L. Gilardi, R. Hugh, R. E. Weaver, and J. A. Webster. 1975. Identification of glucose non-fermenting gram-negative rods. American Society for Microbiology, Washington, D.C.

11. Ensley, B. D., B. J. Ratzkin, T. D. Osslund, M. J. Simon, L. P. Wackett, and D. T. Gibson. 1983. Expression of naphthalene oxidation genes in Escherichia coli results in the biosynthesis of indigo. Science 222:167-169.

11a.Felsenstein, J. PHYLIP (phylogeny inference package), version 3.0. University of Washington, Seattle.

12. Forsberg, C. W., J. W. Costerton, and R. A. MacLeod. 1970. Separation and localization of cell wall layers of a gram-negative bacterium. J. Bacteriol. 104:1338-1353.

13. Gerhardt, P., R. G. E. Murray, R. N. Costilow, E. W. Nester, W. A. Wood, N. R. Krieg, and G. B. Phillips (ed.). 1981. Manual of methods for general bacteriology. American Society for Microbiology, Washington, D.C.

14. Gillis, M., T. V. Van, R. Bardin, M. Goor, P. Hebbar, A. Willems, P. Segers, K. Kersters, T. Heulin, and M. Fernandez. 1995. Polyphasic taxonomy in the genus Burkholderia leading to an emended description of the genus and proposition of Burkholderia vietnamiensis sp. nov. for $\mathrm{N}_{2}$-fixing isolates from rice in Vietnam. Int. J. Syst. Bacteriol. 45:274-289.

15. Grimes, D. J., J. Stemmler, H. Hada, E. B. May, D. Maneval, F. M. Hetrick, R. T. Jones, M. Stoskopf, and R. R. Colwell. 1984. Vibrio species associated with mortality of sharks held in captivity. Microb. Ecol. 10:271-282.

16. Hansen, J. N. 1981. Use of solubilizable acrylamide disulfide gels for isolation of DNA fragments suitable for sequence analysis. Anal. Biochem. 116: 146-151.

17. Holt, J. G., N. R. Krieg, P. H. A. Sneath, J. T. Staley, and S. T. Williams (ed.). 1994. Bergey's manual of determinative bacteriology, 9th ed. Williams \& Wilkins, Baltimore, Md.
18. Jukes, T. H., and C. R. Cantor. 1969. Evolution of protein molecules, p. 21-132. In H. N. Munro (ed.), Mammalian protein metabolism. Academic Press, New York, N.Y.

19. Kado, C. I., and S.-T. Liu. 1981. Rapid procedure for detection and isolation of large and small plasmids. J. Bacteriol. 145:1365-1373.

19a.Kolar, G. W. 1974. M.S. thesis. University of Wisconsin, La Crosse.

20. Krieg, N. R., and J. G. Holt (ed.). 1984. Bergey's manual of systematic bacteriology, vol. 1. Williams \& Wilkins, Baltimore, Md.

21. Kuhn, R., M. P. Starr, D. A. Kuhn, H. Bauer, and H.-J. Knackmuss. 1965. Indigoidine and other bacterial pigments related to 3-3'-bipyridyl. Arch. Mikrobiol. 51:71-84.

22. Lane, D. J., B. Pace, G. J. Olsen, D. A. Stahl, M. L. Sogin, and N. R. Pace. 1985. Rapid determination of $16 \mathrm{~S}$ ribosomal RNA sequences for phylogenetic analysis. Proc. Natl. Acad. Sci. USA 82:6955-6959.

23. MacDonell, M. T., and R. R. Colwell. 1984. Identical 5S rRNA nucleotide sequence of Vibrio cholerae strains representing temporal, geographical, and ecological diversity. Appl. Environ. Microbiol. 48:119-121.

24. MacDonell, M. T., and R. R. Colwell. 1984. Nucleotide sequence of $5 \mathrm{~S}$ ribosomal RNA from Vibrio marinus. Microbiol. Sci. 1:229-231.

25. MacDonell, M. T., and R. R. Colwell. 1985. Phylogeny of the Vibrionaceae, and recommendation for two new genera, Listonella and Shewanella. Syst. Appl. Microbiol. 6:171-182.

26. MacDonell, M. T., and R. R. Colwell. 1986. Ribosomal RNA phylogenies for the vibrio-enteric group of eubacteria. Microbiol. Sci. 3:172-178.

27. Mach, P. A., and D. J. Grimes. 1982. R-plasmid transfer in a wastewater treatment plant. Appl. Environ. Microbiol. 44:1395-1403.

28. Maidak, B. L., N. Larsen, M. J. McCaughey, R. Overbeek, G. J. Olsen, K. Fogel, J. Blandy, and C. R. Woese. 1994. The Ribosomal Database Project. Nucleic Acids Res. 22:3485-3487.

29. Marmur, J. 1961. A procedure for the isolation of deoxyribonucleic acid from microorganisms. J. Mol. Biol. 3:208-218.

30. Marmur, J., and P. Doty. 1962. Determination of the base composition of deoxyribonucleic acid from its thermal denaturation temperature. J. Mol. Biol. 5:109-118.

31. Mayfield, C. I., and W. E. Inniss. 1977. A rapid, simple method for staining bacterial flagella. Can. J. Microbiol. 23:1311-1313.

32. McFadden, B. A., and W. V. Howes. 1961. Pseudomonas indigofera. J. Bacteriol. 81:858-862.

33. Murray, R. G. E., D. J. Brenner, R. R. Colwell, P. De Vos, M. Goodfellow, P. A. D. Grimont, N. Pfennig, E. Stackebrandt, and G. A. Zavarzin. 1990. Report of the Ad Hoc Committee on Approaches to Taxonomy within the Proteobacteria. Int. J. Syst. Bacteriol. 40:213-215.

34. Norton, C. F., and G. E. Jones. 1969. A marine isolate of Pseudomonas nigrifaciens. II. Characterization of its blue pigment. Arch. Mikrobiol. 64: 369-376.

34a.Olsen, G. J. Unpublished data.

35. Olsen, G. J., H. Matsuda, R. Hagstrom, and R. Overbeek. 1994. FastDNAml: a tool for construction of phylogenetic trees of DNA sequences using maximum likelihood. CABIOS 10:41-48.

36. Palleroni, N. J. 1984. Genus I. Pseudomonas Migula 1894, p. 141-199. In N. R. Krieg and J. G. Holt (ed.), Bergey's manual of systematic bacteriology, vol. 1. Williams \& Wilkins, Baltimore, Md.

37. Pot, B., A. Willems, M. Gillis, and J. De Ley. 1992. Intra- and intergeneric relationships of the genus Aquaspirillum: Prolinoborus, a new genus for Aquaspirillum fasciculus, with the species Prolinoborus fasciculus comb. nov. Int. J. Syst. Bacteriol. 42:44-57.

38. Randerath, K., and E. Randerath. 1967. Thin-layer separation methods for nucleic acid derivatives. Methods Enzymol. 12A:323-347.

39. Rayman, M. K., and R. A. MacLeod. 1975. Interaction of $\mathrm{Mg}^{2+}$ with peptidoglycan and its relation to the prevention of lysis of a marine pseudomonad. J. Bacteriol. 122:650-659.

40. Skerman, V. B. D., V. McGowan, and P. H. A. Sneath (ed.). 1980. Approved lists of bacterial names. Int. J. Syst. Bacteriol. 30:225-420.

41. Sneath, P. H. A., and R. R. Sokal. 1973. Numerical taxonomy. W. H. Freeman and Co., San Francisco, Calif

42. Specht, T., J. Wolters, and V. Erdmann. 1990. Compilation of 5S rRNA and 5S rRNA gene sequences. Nucleic Acids Res. 18(Suppl.):2215-2330.

43. Stackebrandt, E., R. G. E. Murray, and H. G. Truper. 1988. Proteobacteria classis nov., a name for the phylogenetic taxon that includes the "purple bacteria and their relatives." Int. J. Syst. Bacteriol. 38:321-325.

44. Stanier, R. Y., N. J. Palleroni, and M. Doudoroff. 1966. The aerobic pseudomonads: a taxonomic study. J. Gen. Microbiol. 43:159-271.

45. Starr, M. P., W. Blau, and G. Cosens. 1960. The blue pigment of Pseudomonas lemonnieri. Biochem. Z. 333:328-334.

46. Stoner, D. L., C. K. Browning, D. K. Bulmer, T. E. Ward, and M. T. MacDonell. 1996. Direct 5S rRNA assay for monitoring mixed-culture bioprocesses. Appl. Environ. Microbiol. 62:1969-1976.

47. Voges, O. 1893. Ueber einige im Wasser vorkommende Pigmentbakterien Zentralbl. Bakteriol. Parasitenkd. Infektionskr. Hyg. Abt. 1 14:301-314.

48. Weisburg, W. G., J. G. Tully, D. L. Rose, J. P. Petzel, H. Oyaizu, D. Yang, L. Mandelco, J. Sechrest, T. G. Lawrence, J. van Etten, J. Maniloff, and C. R. Woese. 1989. A phylogenetic analysis of the mycoplasmas: basis for their 
classification. J. Bacteriol. 171:6455-6467.

49. West, P. A., and R. R. Colwell. 1984. Identification and classification of Vibrionaceae-an overview, p. 285-363. In R. R. Colwell (ed.), Vibrios in the environment. John Wiley \& Sons, New York, N.Y.

50. Woese, C. R., M. Sogin, D. A. Stahl, B. J. Lewis, and L. Bonen. 1976. A comparison of the $16 \mathrm{~S}$ ribosomal RNAs from mesophilic and thermophilic bacilli. J. Mol. Evol. 7:197-213.

51. Yabuuchi, E., Y. Kosako, I. Yano, H. Hotta, and Y. Nishiuchi. 1995. Transfer of two Burkholderia and an Alcaligenes species to Ralstonia gen. nov.: proposal of Ralstonia pickettii (Ralston, Palleroni, and Doudoroff 1973) comb. nov., Ralstonia solanacearum (Smith 1896) comb. nov. and Ralstonia eutropha (Davis 1969) comb. nov. Microbiol. Immunol. 39:897-904. 